\title{
Ancestral Practice in the Production of Cheeses, Attends the Health and Good Living of the Consumer in San Pablo De Atenas, Province of Bolivar (Ecuador)
}

\author{
Ulises Barragán Vinueza ${ }^{1}$, Riveliño Ramón $C^{2}$, José Luis Altuna², Favian Bayas-Morejón',* \\ ${ }^{1}$ Department of Research, Faculty of Jurisprudence and Political Science, State University of Bolivar, Ecuador \\ ${ }^{2}$ Department of Research, Faculty of Agricultural Science, State University of Bolivar, Ecuador
}

Received September 10, 2019; Revised November 8, 2019; Accepted November 11, 2019

Copyright $\subseteq 2020$ by authors, all rights reserved. Authors agree that this article remains permanently open access under the terms of the Creative Commons Attribution License 4.0 International License

\begin{abstract}
This work proposes a claim that institutes a project of entrepreneurship in accordance with the legal situation and economic policies of the popular and solidarity economy for cheese production and under sanitary standards, by establishing a microenterprise where all the inhabitants of the San Pablo area of Athens, considering the productive potential of the area. For which, a questionnaire of 60 people from the area was used. After the analysis, $75 \%$ of respondents say they know the ancestral practices of cheese production. Also, 65\% say they do not know about Micro Enterprise responsible for associating farmers. Likewise, $70 \%$ consider that they are made from cheeses in the ancestral form without observing sanitary norms. In addition, $58 \%$ determine that there are no legal authorizations for the production of ancestral cheese. Finally, $70 \%$ of the respondents agree that a cheese-producing microenterprise will be built in San Pablo de Atenas. In conclusion, it is feasible to open a company that produces artisanal cheeses.
\end{abstract}

Keywords Ancestral Practice, Cheese Production, Popular and Solidary Economy

\section{Introduction}

The protected right is that of companies and their relationship with other legal entities, civil society and the State because the relations of the company with society as a whole are regulated. From another point of view, the Organic Law of the Popular and Solidarity Economy is the form of economic organization where its members individually or collectively organize and develop processes of production, exchange, commercialization, financing and consumption of goods and services to satisfy needs and generate income. In the Art 1 Law of Popular and Solidarity Economy when referring to the popular and solidary economy, it covers a very broad context since it seeks to achieve an economic and social insertion of those excluded from the economy, especially the poorest. In addition, there are already popular economy programs that emphasize the processes of potential solidarity development of the growing economy of food solidarity through collective farms and the closure of the production circle, which benefits the most vulnerable in society (Loh and Agyeman, 2019).

Achieving a progressive transition of the popular economy to the forms of solidarity organization so that its members can strengthen their capacities, socialize their knowledge, achieve better living standards. With regard to the forms of organization of the popular and solidary economy, Art. 2 expresses. The following are forms of organization of the popular and solidary economy and, therefore, the following are subject to the present law:

a) The Popular Socioeconomic Units, such as: single-person undertakings, productive micro-units, home-based workers, retail traders, workshops and small businesses, among others, dedicated to the production of goods and services intended for self-consumption at their sale in the market, through self-employment generate income for self-subsistence.

b) Organizations made up of families, human groups or small communities based on ethnic, cultural and territorial identities, urban or rural, dedicated to the production of goods and services aimed at satisfying their consumption needs and reproducing the conditions of their environment.

c) The economic organizations constituted by farmers, artisans or service providers of identical or complementary nature, who merge their scarce 
resources and individually insufficient factors in order to produce or market in common and distribute among their associates the benefits (associative micro enterprises associations of production of goods or services). Also, it is believed that solidarity economy organizations, community businesses that generally operate in the third sector (nonprofit companies) and are created by members of the communities they serve, have the potential to contribute to a world more sustainable, although it doubts its sustainability over time (Marconatto et al., 2019).

d) Cooperative organizations of all classes and economic activities that constitute the cooperative sector.

e) Integration organizations constituted by the forms of economic organization detailed in this article.

f) The prevalence of work over capital; of collective interests over individual interests; and, of the relations of reciprocity and cooperation over selfishness and competition.

As well as referring to the values of the Art, it determines that: The forms of organization of the popular and solidary economy in their social relations and economic activity will be governed by the values of justice, honesty, transparency and social responsibility; In addition, will base their actions through mutual aid, democratic management, fair trade and ethical consumption.

Article 23 of the Universal Declaration of Human Rights, considers the foundation of international standards on human rights in relation to the Right to Work, indicates; Everyone has the right to work, to free choice of their work, to fair, satisfactory conditions of work and to protection against unemployment. Similarly, the work must have principles of solidarity economy that imply the immediate implementation of the principles of self-determination and cooperation (Bauhardt, 2014).

Everyone has the right, without any discrimination, to equal pay for equal work. The International Covenant on Economic, Social and Cultural Rights, in its Arts. 6, 7, and 8 , collect the Right to Work as one of the economic, social and cultural rights in its articles 6 and 7. The Constitution of the Republic of Ecuador, makes a high recognition of the fundamental principle to work when Art. 325, says: Work is a right and a social duty. It will enjoy the protection of the State, which will assure the worker the respect for their dignity, a decent existence and a fair remuneration that covers their needs and those of their family.

Art. 326, includes certain fundamental rules to be governed as for example among the most important:

1. Labor legislation and its application shall be subject to the principles of social law.

The State will tend to eliminate unemployment and underemployment.

2. The State will guarantee the intangibility of the rights recognized to the workers and will adopt the measures for its extension and improvement.
3. The rights of the worker are inalienable. Any stipulation that implies its resignation, diminution or alteration will be null.

\section{Craft and Ancestral Process}

The story of San Pablo de Atenas refers to the fact that its inhabitants are dedicated specifically to agricultural work, a legacy left by ancestors and that has been transmitted from generation to generation.

The elaboration of cheeses has followed an ancestral process in its elaboration in a traditional way and without counting technologies of the time, elaboration of dairy products that follows a line of an experience or tradition of the past, where its unite the families to generate work teams, what in law we know as work in society, where everyone participates hand in hand to generate production and way of life.

Good Living, in its general conception is not a new concept, it has two original aspects, one in classical Greece with Aristotle and other philosophers, and the Andean world as Sumak Kawsay, this conception, where the citizen is not a person or abstract individual in a direct relationship between individual or State as defended by Robespierre at the beginning of the French Revolution. Our Constitution in the preamble 20, recognizes our millenary roots, forged by women and men of different peoples, celebrates nature, the Pacha Mama, of which we are a part.

\section{Methodology}

The research was qualitative and quantitative; (Qualitative: allows understand the social phenomenon and its characteristics; Quantitative: by descriptive statistics).

\subsection{Types of Investigation}

The present investigation is descriptive, bibliographic and field (surveys).

\subsection{Population and Sample of the Investigation}

A total population of 60 people was used.

\subsection{Methods Applied}

\subsubsection{Inductive - Deductive}

Inductive, because we analyze factors such as: the lack of advice on corporate law that allows for the creation of a micro-enterprise that strengthens the association of agricultural livestock producers for the production and production of cheeses in San Pablo de Atenas, San Miguel following traditional ancestral patterns.

Deductive, because we detail the entire structure of the legal regulations related to the constitution of a micro company that allows associating the community work of 
livestock farmers.

\subsection{Applied Techniques}

Transfer. - It was used to include data listened to, alone or in combination.

Direct observation. - It was used with greater importance because a continuous field work was carried out to determine the influences that intervene in this phenomenon.

Surveys. - They were made to cheese producers and consumers or population.

\subsection{Research Instruments Applied}

The instruments that were used for this investigation were: Observation Guide and Questionnaires.

\section{Interpretation and Analysis of Results}

Result of surveys carried out on the inhabitants of San Pablo de Atenas

QUESTION N ${ }^{\circ} 1$ Do you know about the ancestral practices of cheese production in San Pablo de Atenas?

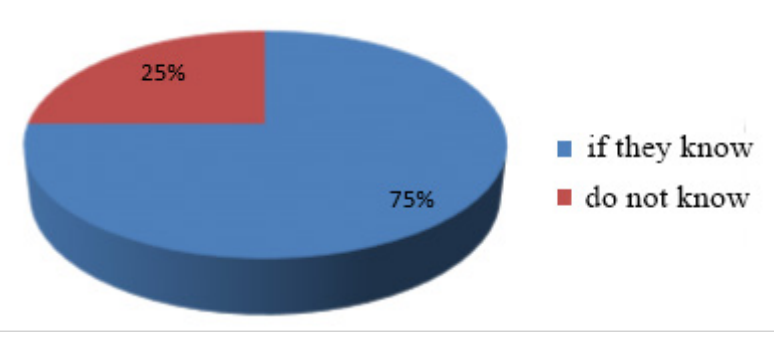

From the statistical results obtained, it can be determined that 15 of the respondents do not know about ancestral practice for cheese making while 45 people know about the ancestral practice of elaboration cheeses.

QUESTION N ${ }^{\circ} 2$ Do you know the existence of a Micro Company responsible for associating the Agro Cattle Ranchers of San Pablo de Atenas, San Miguel de Bolivar for the elaboration of cheeses.

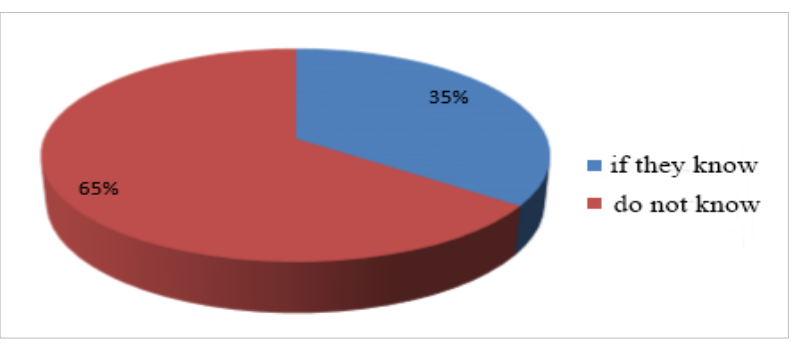

It can be seen from the results obtained that 27 of the respondents know that they work in families, and in contrast 43 are unaware of the existence of a Micro
Company that associates livestock farmers for the production of cheeses.

QUESTION N ${ }^{\circ} 3$ Do you think that the elaboration of cheeses in the ancestral way without observing sanitary norms affects to the right of the Good Living of the Population?

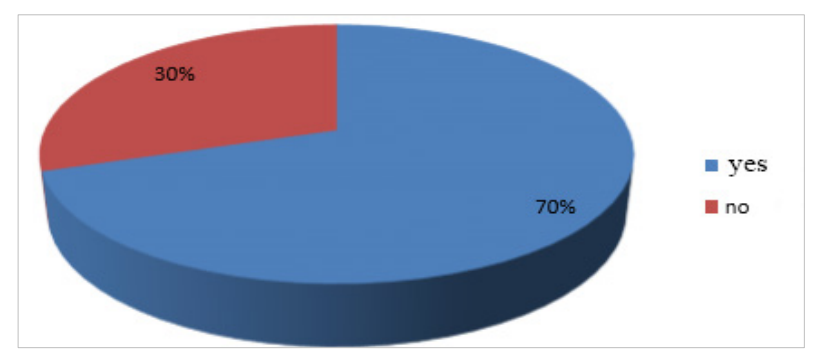

In this sense, 42 respondents consider that the elaboration of artisanal cheeses without observing sanitary norms if it threatens the right to Good Living of the population, while 18 of the respondents assure that it does not affect.

QUESTION N ${ }^{\circ} 4$ Do you believe that there are legal and technical authorizations for the production of ancestral and industrial cheese?

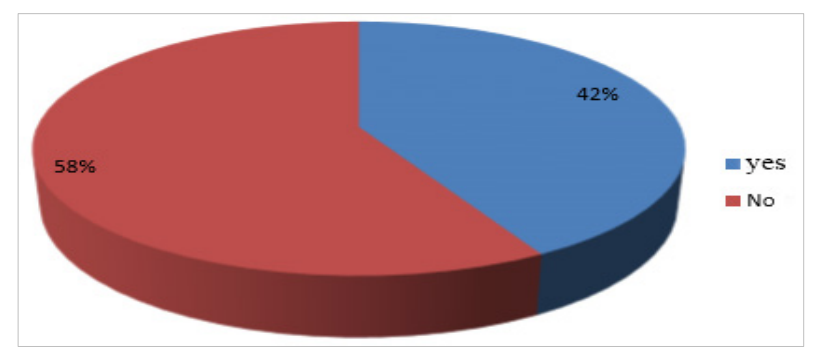

Of the total number of respondents, 25 people know about the legal existence and techniques for making cheeses in an ancestral way and 35 do not know about the legal existence and techniques for making ancestral and industrial cheeses.

QUESTION $\mathrm{N}^{\circ} 5$ Are you in agreement with the Constitution of a Micro Company that associates the Agro Cattle Ranchers of San Pablo de Atenas, San Miguel de Bolivar that allows the community development in the elaboration of quality cheeses?

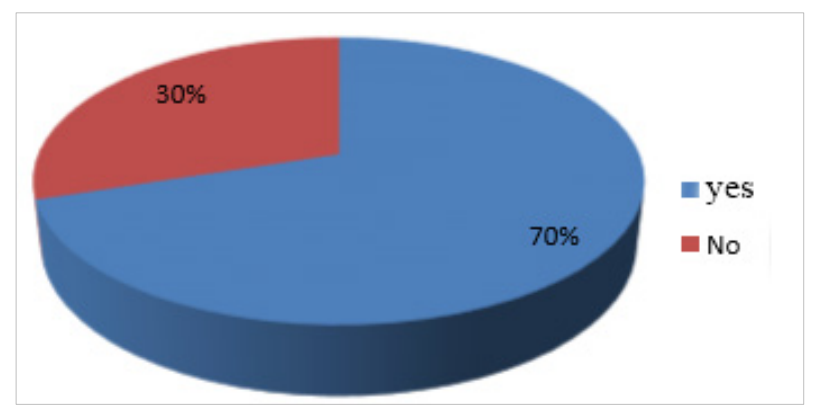

In relation to this question, 18 respondents consider not to be in agreement with the constitution of a Micro 
Company that associates the Agro Cattle Ranchers of San Pablo de Atenas, which allows the community development in the elaboration of cheeses of quality, not so $70 \%$ that, if you agree, which makes our Legal proposal valid.

While it is true that our geographical environment located in the central part of the Ecuadorian highlands, we must refer to the progressive San Pablo de Atenas, San Miguel canton, Province of Bolivar has experienced a Jurisprudential stage based on knowledge and ancestral knowledge in the Regarding the production of cheese, being an eminently Agro-Livestock Region, initially having been the Agro Livestock exploited by people who exercised acts of trade with milk to move all production to warehouses, which is Babahoyo, then the desire to generate economy family development has allowed families in the rural sector join their efforts and proceed to the traditional way.

After the analysis, the level of feasibility is acceptable, however, we must take into consideration that in the province of Bolivar the main cause of bankruptcy of small businesses is not only due to deficiencies in management, lack of capital or administrative problems, lack of organization and control, but also, in problems directly related to the market, one must take into account the criteria of Portalanza (2012) that indicated "what is not promoted, is not sold" (Moposita et al., 2018).

In conclusion, the lack of social organization means that the inhabitants of the urban, rural communes of the San Pablo de Atenas carry out acts of trade individually, attending to the milk production on a minimal scale. In this sense, the elaboration of ancestral and artisan cheese attends to the health rights of the population in San Pablo.

\section{REFERENCES}

[1] Bauhardt C. (2014). Solutions to the crisis? The Green New Deal, Degrowth, and the Solidarity Economy: Alternatives to the capitalist growth economy from an eco-feminist economics perspective, Ecological Economics, Volume 102: 60-68, ISSN 0921-8009, https://doi.org/10.1016/j.ecol econ.2014.03.015.

[2] Constitution of the Republic of Ecuador (2008). (Constitución de la República del Ecuador); preámbulo pág. 1, Art 315, Art. 326 Ibídem.

[3] Davalos P. (2013). Reflexiones sobre el Sumak Kawsay, y las teorías del desarrollo.

[4] From the Universal Declaration of Human Rights (De la Declaración Universal de Derechos Humanos). 10 Art 23.

[5] Gaibor V. Historia del Cantón San Miguel y sus Parroquias.

[6] International Covenant on Economic, Social and Cultural Rights (Pacto Internacional de Derechos Económicos Sociales y Culturales). 11 Art 6, 7.
[7] Law of Popular and Solidarity Economy (Ley de Economía Popular y Solidaria). 9 Art 4, 7 Art 1, 8 Art 2.

[8] Loh P and Agyeman J. (2019). Urban food sharing and the emerging Boston food solidarity economy, Geo-forum, Volume 99: 213-222, ISSN 0016-7185.https://doi.org/10.1 016/j.geoforum.2018.08.017.

[9] Marconatto D, Ladeira W, Wegner D. (2012). The sustainability of solidarity economy organizations: An empirical investigation, Journal of Cleaner Production 228: 1122-1130, ISSN 0959-6526, https://doi.org/10.1016/j.jcle pro.2019.04.352.

[10] Moposita D, Núñez D, Castro V, Ramón R, Barragán U, Segura J, Guamán J, Arcos V, García I, Calderón A, Bayas-Morejón F. (2018). The Strategic Marketing in the Process of Sales of the Pulpes of Fruits Processed in the Agrotal Factory of Echeandia, Province of Bolivar (Ecuador). International Business Management 12(6): 442-446. DOI: 10.3923/ibm.2018.442.446.

[11] Portalanza C (2012). Low promotion is the cause for scarce tourism development. El Telégrafo, Guayaquil, Ecuador. 